\title{
腫瘍による気管狭窄
}

$\begin{array}{lll}\text { 雨宮 } & \text { 隆太, 郡 } \text { 国 光, 輿 石 晴也 } \\ \text { 高橋 英介, 内藤 淳, 於保 健 吉 }\end{array}$

\section{Primary and Metastatic Tracheal Tumors with Airway Stenosis}

\author{
Ryuta Amemiya, M.D., Shao Guo Guang, M.D., Haruya Koshiishi, M.D., \\ Eisuke Takahashi, M.D., Jun Naitoh, M.D., and Kenkichi Oho, M.D. \\ Department of Surgery, Tokyo Medical College, Tokyo
}

\begin{abstract}
Since 1980, we began applying fiberoptic bronchoscopic Nd-YAG laser treatment for tracheal-carinal tumors. Endoscopic Nd-YAG laser treatment and adjuvant therapy were performed in 16 cases of primary tracheal tumor (12 malignant lesions and 4 benign lesions) and 39 cases of metastatic tracheal lesions. For 28 cases presenting severe respiratory distress, the procedure was performed as an emergency life-saving procedure and dramatic improvement in condition was seen in 26 cases $(92.9 \%)$. Twenty seven cases were treated by staged laser reduction of the residual airway lesion. Effectiveness was observed in 24 cases $(88.9 \%)$. In these cases, after Nd-YAG laser treatment for ventilatory improvement, local or systemic adjuvant therapy was performed. Local adjuvant therapy was performed in 29 cases, 11 cases were treated surgically ( 4 tracheoplasties and 10 treacheal tube stent operations) and 28 cases underwent radiotherapy.

In addition to these cases, there were 5 cases who underwent tracheal resection without preoperative $\mathrm{Nd}$-YAG laser treatment. These 5 cases consisted of 3 tracheal tumors and 3 metastatic lesions from the thyroid gland.

Bronchoscopic Nd-YAG laser treatment is a relatively new method for the treatment of tracheal or carinal tumor with ventilatory disturbance due to airway stenosis.
\end{abstract}

\footnotetext{
Key words : 気管腫瘍, 腫瘍性気管狭窄, 気管支鏡的 Nd-YAGレーザー治療, 気管形成術, 気管 チューブ内固定留置術
}

\section{I 、はじめに}

気管を狭窄する原発性, 転移性腫瑒は呼吸器

東京医科大学外科

別刷請求： 个160 東京都新宿区西新宿6-1-1

東京医科大学外科 雨宮隆太

投稿受付：1990年 5 月 12 日
症状がある例であっても胸部X線写真で気管の

透亮像の狭小化を見逃されていることが多い。 一般には息切れや喘鳴，血疢などの症状から気 管支喘息や慢性気管支炎として長期間治療さ れ，換気障害の増強により初めて気管を狭窄す る病変が疑われて, 断層撮影や内視鏡検查が行 われている。 


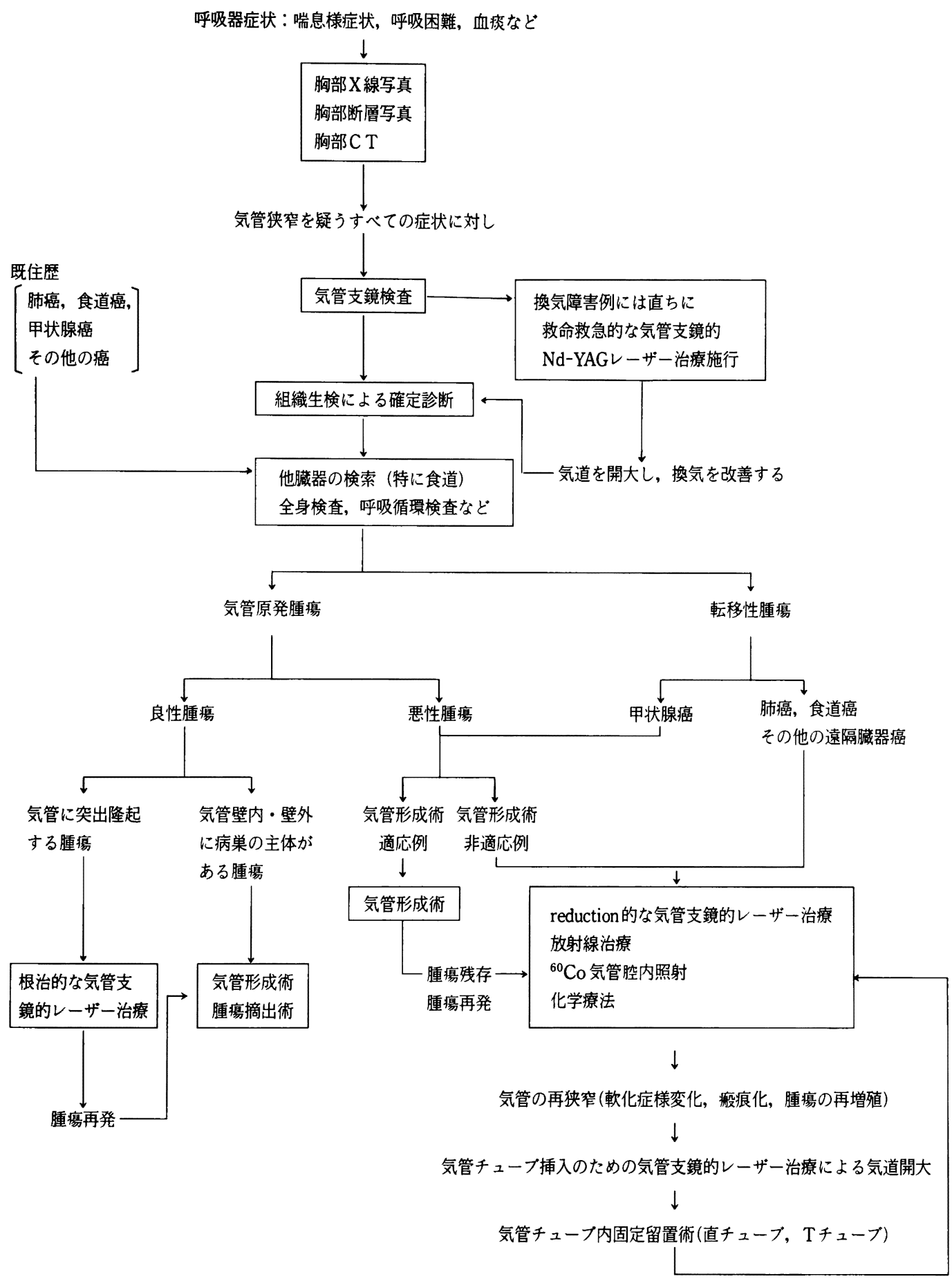

図 1 腫瘍性気管狭窄病変に対する治療方針 
1980年に入り，本邦では気管支ファイバース コープや, CT の機器の改良と普及による呼吸 器の画像診断法が著しく進歩し, また, 治療面 では従来行われてきた気管形成術に加え, 気管 支鏡的Nd- YAGレーザー治療が導入された。 そのために，気管を狭窄する腫瘍性病変に対す る診断・治療の報告例が増加している。

本稿では，教室において経験した気道を狭窄 する腫瘍性病変の診療経験を基に, 治療方針の
考え方 (図 1$)^{1)}$ と予後の改善に最も役立つ内視 鏡的レーザー治療法，外科的治療法の概要につ いて述べる。

\section{II．気管を狭窄する腫嫊性病変の分類}

腫瘍による気管狭窄は原発性気管腫瘍(悪性, 良性), 他臓器癌からの直接気管浸潤あるいは気 管への血行性転移病巣によって発生する。浸潤 性, 転移性の腫揚は原発臟器より肺癌, 気管に

表 1 気管に増殖する腫瘍性病変に対する Nd-YAGレーザー治療例

\begin{tabular}{|c|c|c|c|c|c|c|c|c|c|}
\hline \multicolumn{3}{|c|}{ 原 発 部位と組 織 型 } & 症例 & \multicolumn{2}{|c|}{ レーザー治療目的 } & $\begin{array}{l}\text { 効 果 の } \\
\text { あった例 }\end{array}$ & $\begin{array}{l}\text { レーザー後 } \\
\text { 気管形成術 } \\
\end{array}$ & $\begin{array}{l}\text { レーザー後気管千 } \\
\text { ューフ十内固定留置 } \\
\end{array}$ & $\begin{array}{l}\text { レーザー後 } \\
\text { 放射線治療 }\end{array}$ \\
\hline \multirow{3}{*}{\multicolumn{2}{|c|}{ 気管原発悪性腫瘍 }} & 腺様豊胞癌 & 8 & $\begin{array}{l}\text { 救命救急的 } \\
\text { reduction的 }\end{array}$ & & $\begin{array}{l}6 \\
2 \\
\end{array}$ & $\begin{array}{l}4 \\
0 \\
\end{array}$ & $\begin{array}{l}3 \\
0 \\
\end{array}$ & $\begin{array}{l}6 \\
0 \\
\end{array}$ \\
\hline & & 扁平上皮癌 & 3 & 救命救急的 & 3 & 3 & 0 & 2 & 3 \\
\hline & & 小細胞癌 & 1 & 救命救急的 & 1 & 1 & 0 & 0 & 1 \\
\hline \multirow{3}{*}{\multicolumn{2}{|c|}{ 気管原発良性腫瘍 }} & 多形腺腫 & 2 & $\begin{array}{l}\text { 救命救急的 } \\
\text { reduction的 }\end{array}$ & & $\begin{array}{l}1 \\
1 \\
\end{array}$ & $\begin{array}{l}0 \\
0 \\
\end{array}$ & $\begin{array}{l}0 \\
0\end{array}$ & $\begin{array}{l}0 \\
0\end{array}$ \\
\hline & & 過 誤 腫 & 1 & reduction的 & 1 & 1 & 0 & 0 & 0 \\
\hline & & 神経鞘腫 & 1 & reduction的 & 1 & 1 & 0 & 0 & 0 \\
\hline \multirow{9}{*}{$\begin{array}{l}\text { 気管への } \\
\text { 転移病変 }\end{array}$} & \multirow{3}{*}{ 肺癌 } & 扁平上皮癌 & 5 & $\begin{array}{l}\text { 救命救急的 } \\
\text { reduction的 }\end{array}$ & $\begin{array}{l}3 \\
2 \\
\end{array}$ & $\begin{array}{l}3 \\
2 \\
\end{array}$ & $\begin{array}{l}0 \\
0\end{array}$ & $\begin{array}{l}0 \\
0\end{array}$ & $\begin{array}{l}3 \\
2\end{array}$ \\
\hline & & & 2 & $\begin{array}{l}\text { 救命救急的 } \\
\text { reduction的 }\end{array}$ & $\begin{array}{l}1 \\
1\end{array}$ & $\begin{array}{l}1 \\
1\end{array}$ & $\begin{array}{l}0 \\
0\end{array}$ & $\begin{array}{l}0 \\
0\end{array}$ & $\begin{array}{l}1 \\
0\end{array}$ \\
\hline & & 大細胞癌 & 1 & 救命救急的 & 1 & 1 & 0 & 1 & 1 \\
\hline & 食 & & 11 & $\begin{array}{l}\text { 救命救急的 } \\
\text { reduction的 }\end{array}$ & $\begin{array}{l}2 \\
9 \\
\end{array}$ & $\begin{array}{l}2 \\
7 \\
\end{array}$ & $\begin{array}{l}0 \\
0\end{array}$ & $\begin{array}{l}2 \\
1\end{array}$ & $\begin{array}{l}2 \\
4\end{array}$ \\
\hline & 甲 & 腺 & 6 & $\begin{array}{l}\text { 救命救急的 } \\
\text { reduction的 }\end{array}$ & $\begin{array}{l}3 \\
3 \\
\end{array}$ & $\begin{array}{l}3 \\
2 \\
\end{array}$ & $\begin{array}{l}0 \\
0 \\
\end{array}$ & $\begin{array}{l}1 \\
0\end{array}$ & $\begin{array}{l}0 \\
0\end{array}$ \\
\hline & 咽 & 頭 & 1 & reduction的 & 1 & 1 & 0 & 0 & 0 \\
\hline & 乳 & 癌 & 1 & reduction的 & 1 & 1 & 0 & 0 & 0 \\
\hline & 胃 & 癌 & 1 & reduction的 & 1 & 1 & 0 & 0 & 0 \\
\hline & $\mathrm{C}$ & $\mathrm{L}$ & 1 & reduction的 & 1 & 1 & 0 & 0 & 0 \\
\hline \multirow{6}{*}{$\begin{array}{l}\text { 気管・気管 } \\
\text { 支への転移 } \\
\text { 病変 }\end{array}$} & \multirow{3}{*}{ 肺癌 } & 扁平上皮癌 & 4 & 救命救急的 & 4 & 2 & 0 & 0 & 3 \\
\hline & & 腺 & 1 & 救命救急的 & 1 & 1 & 0 & 0 & 1 \\
\hline & & 大細胞癌 & 1 & 救命救急的 & 1 & 1 & 0 & 0 & 1 \\
\hline & 食 & 癌 & 2 & $\begin{array}{l}\text { 救命救急的 } \\
\text { reduction的 }\end{array}$ & $\begin{array}{l}1 \\
1 \\
\end{array}$ & $\begin{array}{l}1 \\
1 \\
\end{array}$ & $\begin{array}{l}0 \\
0 \\
\end{array}$ & $\begin{array}{l}0 \\
0 \\
\end{array}$ & $\begin{array}{l}1 \\
0 \\
\end{array}$ \\
\hline & 結 & 癌 & 1 & reduction的 & 1 & 1 & 0 & 0 & 0 \\
\hline & 腎 & 癌 & 1 & reduction的 & 1 & 1 & 0 & 0 & 0 \\
\hline
\end{tabular}


隣接して発生する甲状腺癌や食道癌, 遠隔臟器 癌の 3 種に大別することができる。

教室における原発性気管腫瘍は，表 1 の16例 に表 2 の No. 5 腺様豊胞癌, No. 6 平滑筋腫を 加えた悪性腫瘍13例, 良性腫瘍 5 例である。こ のような組織型別の頻度は井上ら ${ }^{20}$ の全国統計 と大差なく, 気管腫瘍の $75 \%$ 前後が悪性腫瘍で ある。

悪性腫瘍では腺様囊胞癌が $60 \%$ 前後を占め, 次いで扁平上皮癌が多い。腺様囊胞癌は唾液腺 に似た構造を示す気管腺より発生し, 通常経験 する肺癌（扁平上皮癌や腺癌など）とは異なっ た独特の増殖進展様式を示す。

腺様豊胞癌は表面が粘膜上皮に被覆され, 気 管壁内で全周性に軟骨を㣣んで内側と外側にサ ンドイッチ状に広範囲に浸潤増殖する傾向が強 く, 気管が絞扼性に狭窄する(図 2 )。腫瘍の一 部は結節隆起状の増生をして気管内に突出する ことがあるが, 気管原発例は気管支原発例に比 べ,ポリープ状の発育が乏しい傾向にある（図 3 )。腺様囊胞癌のこのような増殖形態は早期発 見, 腫瘍浸潤範囲の臨床的, 病理学的診断の困 難性落)を物語っている。

気管・気管分岐部への肺癌を含む転移性気管 腫瘍 (表 1) は, 全例が種々の気管狭窄を呈し, 何らかの呼吸器症状を認めた。転移性病変は肺 原発腫場が最も多く, 特に, 肺門部発生の扁平 上皮癌例の中に主気管支から連続性に気管にま



图 2 腺様哓胞癌の気管管状切除標本（表 2 の症例 2 と同一例)

粘膜上皮と軟骨を除きすべて腫痬である。

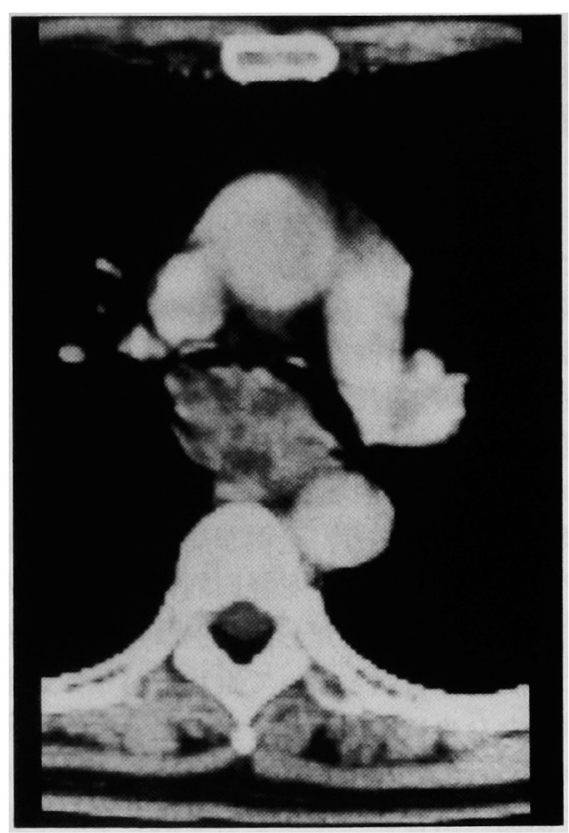

图 3 気管分岐部に発生した腺様襄胞癌の CT 像 (表 2 の症例 4 と同一例)

膜様部より気管内に隆起する腫瘍。前側にわずかに 左右の主気管支が開残している。

で増殖して, 気道を狭窄する傾向が強くみられ た。次いで, 気管に接する食道癌と甲状腺癌の 原発巣あるいはリンパ節転移巣からの狭窄病変 が多くみられた。中には気管狭窄による換気障 害の治療中に, 初めて甲状腺癌や食道癌が発見 された例もある。

扁平上皮癌の気管狭窄例は気管原発癌, 食道 癌, 肺癌との鑑別診断を常に考慮するよう注意 しなけれならない（図 1)。

\section{III. 腫瘍による気管狭窄に対する救命救急的 治療}

気管から気管分岐部に増殖する腫瘍の中には 激しい換気障害を訴えて, 初めて気管の病変を 診断されることが多い。特に換気障害を伴う悪 性腫瘍は治療困難な病変が多いため, NdYAGレーザー治療導入前は急速な症状の悪化 により，なす術もなく多くの患者が不幸な転機 をとっていた。

気管支鏡的に行うNd- YAGレーザー治療 
は，気管から区域気管支までの軟骨より内側に 増殖する良性・悪性の気道内病変を短時間に焼 灼昇華（vaporization）することが可能なため に，われわれは1980年以後このような症例に Nd- YAGレーザーを用いた換気改善を目的と した気道開大の治療を行っている。特に激しい 呼吸困難例には原発性, 転移性の区別なく, 救 命救急的治療が行われる6。

また，呼吸困難の乏しい気管狭窄例に対して は換気障害を予防する目的で気道内の腫瘍量を 減少させる reduction 的治療を行っている。

表 1 に示す症例は，全例が局所麻酔下に気管 支ファイパースコープを経口的に直接に挿入し て治療を行った。ただし，2 例はレーザー治療 中に，腫瘍が舌状となって垂れ下がって気道を 狭窄したために，插管して食道癌の治療に多用 される retrogradeの手技5を用いて，末梢側よ り中枢側に気管チューブを引き抜きながら腫瘍 を焼灼昇華した。残りの53例は中枢側より末梢 側に向かって挿管することなく, prograde に腫 瘍を昇華焼灼することが可能であった。

Nd- YAGレーザーは20〜 $60 \mathrm{~W}$ ，主に $40 \mathrm{~W}$ の 2 秒断続波にて, プロープ先端部を病巣部位 から約 $1 \mathrm{~cm}$ の距離をおいて非接触性にレーザ 一光を反復照射した ${ }^{7,8)}$ 。照射は気道がわずかに 残存している部分から始め, 気道内径が全域に 渡り $7 \sim 8 \mathrm{~mm}$ 以上に開大することを第一目 標とした ${ }^{8)}$ 。照射部位は病巣の根部や中心部で なく, 辺緑の気道が残存している部分を目標と して照射する（図 4,5)。根部よりの照射は前 述したように病巣の一部が舌状に垂れ下がり,

気道内腔をより狭窄する危険性がある。レーザ 一治療中，気管支鏡の插入による気道内腔の狭 小と，発生した煙により換気障害がますます強 くなり, $\mathrm{PaO}_{2} 40$ torr 以下, $\mathrm{PaCO}_{2} 80$ torr 以 上になる例をみる。レーザー治療中の呼吸管理 は経鼻的酸素投与を行いながら，経皮的に酸素 飽和度を計測して状態を把握する。

しかし，換気障害の著しい例 $\left(\mathrm{SO}_{2} 80 \%\right.$ 以下) では，病巣末梢側の健状気管支まで気管支鏡を 插入し，気管支鏡の生検チャンネルより酸素を 噴射することにより，酸素飽和度が回復する。 その後はレーザー照射と酸素の噴射を交互に行 って治療を続行する。

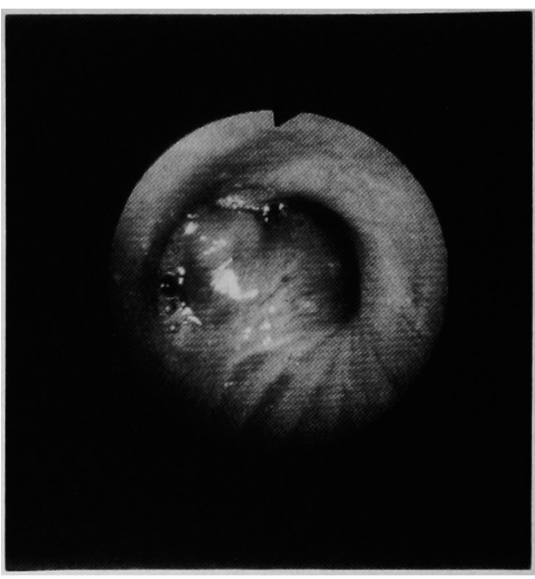

图 4 気管分岐部に発生した腺様襄胞癌（表 2 の症 例 4 と同一例)

粘膜上皮に被覆された腫瘍が気管を狭窄している。



図 5 図 4 と同一例の内視鏡的Nd- YAG レーザー 治療後

左右主気管支は開大している。

症例の過半数 (51\%) は治療前, 酸素投与下 に $\mathrm{PaO}_{2} 70$ torr 以下（最悪例 40 torr）であっ た。気管・気管分岐部の腫瘍性病変に対する救 命救急的・ reduction 的な気道の開大は短時間 ( $1 \sim 3$ 時間)に $91 \%$ の症例に対し目的を達成す ることが可能であり，レーザー出力は常に 10,000 Joules を越える力量が必要であった。表 1 の救命救急的治療の対象とした症例は $\mathrm{PaO}_{2}$ 70 torr 未満か $\mathrm{PaCO}_{2} 45$ torr 以上の換気障害 を示す高度気管狭窄例である。 
救命救急的気道開大を行った 28 例のうち, 所 期の目的達成率は $92.9 \%$ であった。レーザー治 療が効果ありと判定した26例の血液ガスの值 は, 全例が $\mathrm{PaO}_{2} 60$ torr 以上, $\mathrm{PaCO}_{2} 40$ torr 以下に改善した ${ }^{9)}$ 。 reduction 的治療による気道 開大は27例に行い, 所期の目的達成率は $88.9 \%$ である。レーザー治療による換気障害の急速な 改善や換気障害に陥る危険性が回避された後 に, 各症例に適した後療法を行っている。

原発性腫湯の中には次項に述べるように, 気 管形成術の適応となる例がある。手術不能な原 発性腫痬や転移性腫瘍例は, 化学療法と放射線 療法のどちらか, あるいは両者を行い, 各症例 に適した後療法を行って予後の改善に努力しな ければならなかった。

\section{IV．腫瘍による気管狭窄例に対する気管手術}

気管の外科治療は, 開胸術による気管切除と 気管形成術あるいは種々のタイプの気管チュー ブを気管内に固定する手技がある ${ }^{10,11)}$ 。外科的 治療が必要であった 18 例の $88.9 \%$ ，何らかの 換気障害に陥っていた。術前に内視鏡的レーザ 一治療, あるいは電気メス切除の行われなかっ た 4 例（表 2 ）を除き， 5 例の気管切除例は術 前治療にて気管を開大することにより, 全身状 態が改善し，術後管理が容易になった。

気管内固定チューブ留置例は, 術前レーザー 治療が必須であり, 原疾患の治療が可能となる ため, 予後の延長が見られた。われわれの経験 した初期の症例は, レーザー治療後, 必要に迫

表 2 腫瘍性気管狭窄の気管形成術例

\begin{tabular}{|c|c|c|c|c|c|c|c|c|c|}
\hline No & 年路命性 & 疾患名 & 部 位 & 手術術式 & 切除範囲 & 術前治療 & 合併症/再発 & 術後治療 & 予 \\
\hline 1 & $40 / \mathrm{M}$ & 腺様粪胞癌 & 気管下部 & $\begin{array}{l}\text { 気管環状切除 } \\
\text { 気管形成術 }\end{array}$ & $3.9 \mathrm{~cm}$ & $\begin{array}{l}\text { 救命救急的 } \\
\text { Nd-YAGレーザー治境 }\end{array}$ & なし & 施行せず & 生存：9年 3 月 \\
\hline 2 & $37 / \mathrm{F}$ & 腺様栾胞癌 & $\begin{array}{l}\text { 気管上部 } \\
\text { 下部 }\end{array}$ & $\begin{array}{l}\text { 気管環状切除 } \\
\text { 気管形成術 }\end{array}$ & $4.5 \mathrm{~cm}$ & $\begin{array}{l}\text { 救命救急的 } \\
\text { Nd-YAGレーザー治療 }\end{array}$ & $\begin{array}{l}\text { 吻合部離解 } \\
\text { 吻合部狭窄 }\end{array}$ & $\begin{array}{l}\text { Nd-YAGレーザー治療 } \\
\text { 気管チューフ内固定 }\end{array}$ & $\begin{array}{l}\text { 死亡： } 1 \text { 年 } 5 \text { 月 } \\
\text { 気道内出血 }\end{array}$ \\
\hline 3 & $43 / F$ & 腺様垂胞癌 & $\begin{array}{l}\text { 気管上部 } \\
\text { ～下部 }\end{array}$ & $\begin{array}{l}\text { 気管環状切除 } \\
\text { 気管形成術 }\end{array}$ & $2.0 \mathrm{~cm}$ & $\begin{array}{l}\text { 救命救急的 } \\
\text { Nd-YAGレーザー治療 }\end{array}$ & なし & $\begin{array}{l}\text { 予防的胿内放射線照 } \\
\text { 射 }\end{array}$ & 生存: 3 年 8 月 \\
\hline 4 & $61 / F$ & 腺様㑒胞癌 & $\begin{array}{l}\text { 気管分岐 } \\
\text { 部 }\end{array}$ & $\begin{array}{l}\text { 分岐部切除 } \\
\text { 二連銃型再建 } \\
\text { 有茎春柱起立筋被覆 }\end{array}$ & $4.0 \mathrm{~cm}$ & $\begin{array}{l}\text { 救命救急的 } \\
\text { Nd-YAGレーザー治療 }\end{array}$ & $\begin{array}{l}\text { 吻合部離解 } \\
\text { 吻合部狭窄 }\end{array}$ & $\begin{array}{l}\text { Nd-YAGレーザー治療 } \\
\text { 放射線照射 }\end{array}$ & $\begin{array}{l}\text { 死亡：8月 } \\
\text { 呼吸不全, DIC }\end{array}$ \\
\hline 5 & $65 / \mathrm{M}$ & 腺様軎胞癌 & $\begin{array}{l}\text { 気管中部 } \\
\text { ～右主幹 }\end{array}$ & $\begin{array}{l}\text { 膜様部切除 } \\
\text { 人工血管補填 }\end{array}$ & $7.5 \mathrm{~cm}$ & $\begin{array}{l}\text { 換気障害に対する } \\
\text { 内視鏡的電気メス切 } \\
\text { 除 }\end{array}$ & $\begin{array}{l}\text { 補填物質脱落 } \\
\text { 全身転移 }\end{array}$ & $\begin{array}{l}\text { 放射線照射 } \\
\text { 化学療法 }\end{array}$ & $\begin{array}{l}\text { 死亡 : } 9 \text { 年 } \\
\text { 悪液質 }\end{array}$ \\
\hline 6 & $67 / M$ & 平滑筋腫 & $\begin{array}{l}\text { 下部気管 } \\
\text { 膜様 }\end{array}$ & $\begin{array}{l}\text { 腪瘦摘除術 } \\
\text { 膜様部縫合 }\end{array}$ & $(3 \mathrm{~cm})$ & 施行せず & なし & 施行せず & 生存: 5 年 5 月 \\
\hline 7 & $39 / \mathrm{F}$ & $\begin{array}{l}\text { 甲状腺癌 } \\
\text { 術後再発 }\end{array}$ & 上部気管 & $\begin{array}{l}\text { 気管環状切除 } \\
\text { 気管形成術 }\end{array}$ & $2.0 \mathrm{~cm}$ & 施行せず & $\begin{array}{l}\text { 気道内出血 } \\
\text { 気管の虚脱 } \\
\text { 呼吸不全 }\end{array}$ & 気管切開 & 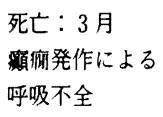 \\
\hline 8 & $68 / \mathrm{F}$ & 甲状腺癌 & 上部気管 & $\begin{array}{l}\text { 気管環状切除 } \\
\text { 気管形成術 } \\
\text { 有茎性大網 } \\
\text { 被覆 }\end{array}$ & $5.5 \mathrm{~cm}$ & 施行せず & \begin{tabular}{|l} 
両側反回神経 \\
マヒ \\
誤飲性肺炎
\end{tabular} & 予防的気管切開 & $\begin{array}{l}\text { 死亡：1.5月 } \\
\text { 肺炎による呼吸 } \\
\text { 不全 }\end{array}$ \\
\hline 9 & $67 / \mathrm{F}$ & 甲状腺癌 & $\begin{array}{l}\text { 甲状・輪 } \\
\text { 状軟骨 } \\
\text { 上部気管 }\end{array}$ & $\begin{array}{l}\text { 甲状·输状軟 } \\
\text { 骨部切除 } \\
\text { 気管環状切除 } \\
\text { 気管形成術 } \\
\text { 有茎性胸鎮乳 } \\
\text { 突筋被覆 }\end{array}$ & $6.0 \mathrm{~cm}$ & 施行せず & $\begin{array}{l}\text { 右側反回神経 } \\
\text { マヒ }\end{array}$ & 予防的気管切開 & 生存：7月 \\
\hline
\end{tabular}


られて外科治療を行ったが, 最近の症例は外科 治療を目的としてレーザー治療を計画する例が みられるようになっている。

\section{a . 気管切除（形成術を含む）}

腫瘍病変に対する気管切除例は 9 例あり, 腺 様襄胞癌 5 例, 甲状腺癌 3 例, 平滑筋腫 1 例で ある(表 2 )。症例 1，2，3 は気管を環状切除し， 端々吻合による気管形成術にて再建した。症例 4 は気管分岐部切除と 2 連銃式の分岐部再建を 行った。症例 5 は膜様部に $7 \mathrm{~cm}$ 以上の腫瘍が あり, 膜様部を長軸方向で $7.5 \mathrm{~cm}$ 切除し, Woven Dacron の人工血管を用いて，欠損部を 補填した。症例 6 は膜様部の上皮下腫瘍を摘出 し, 粘膜の欠損部を一期的に縫合し治痛せしめ た。症例 $7,8,9$ は頸部気管を甲状腺癌ととも に合併切除し，端々吻合にて再建した。環状切 除例の切除距離は $2.0 \mathrm{~cm}$ から $6.0 \mathrm{~cm}$ まで, 2 軟骨輪から 8 軟骨輪あるいは甲状軟骨の一部ま でを切除している。

気管形成術例の致死的合併症は縫合不全であ る。吻合部に対する組織被覆は意義がないとい う報告 ${ }^{12)}$ もるが，食道との剥離が広範囲とな つた例や，吻合部に緊張のかかる例に対しては 予防的に脊柱起立筋, 胸鎖乳突筋, 大網あるい は内胸動脈の脂肪織を有茎にして吻合部を被覆 し, 離解部の補填と気管支循環の早期再開を目 的とした処置を行っている。

われわれの症例に術死はないが，5例が死亡 している。症例 2 は腫瘍増殖範囲の術前診断を 誤り，端々吻合した両側に腫湟が広範囲に残存 し, 自宅で腫瘍再増殖巣からの気道内出血で 1 年 5 力月後に急死した。症例 4 は部分的な吻合 離解部の肉芽組織の増殖により突然に自宅で換 気不全を呈し，当院に転送されたが DIC を併発 して 8 カ月で死亡した。症例 5 は腫瘍の遠隔転 移と悪液質にて 9 年後に死亡した。

症例 7 は小览期より頡癇の内服治療を受けて おり, 術直後には低酸素状態になると㿗痌発作 が頻発し，插管やレスピレーターによる管理が 必要であった。術後 3 力月して病棟内を歩行し, 食事摂取が可能となっていた。予防的な気管切 開が行われていたにもかかわらず，唾液誤飲に よる低酸素状態により廎癇発作を起こし, 気道 内粘液を喀出できずに呼吸不全にて死亡した。
症例 8 は嬹下性肺炎による呼吸不全にて 1.5 カ月にて死亡した。症例 7,8 は術後両側反回神 経麻舫を起こしたことが死因の要因となってい た。それゆえに, 最近の例では腫湯内に反回神 経が巻き込まれていても，健側の神経は可能な 限り温存して, 合併症を回避するように心掛け ている。

\section{b. 気管内固定チュープ留置術}

気管形成術の対象とならない気管狭窄例の治 療は気道腔内から狭窄を防止し, 気管を保持し なければならない。特に,レーザー治療後の腫 瘍の再増殖による気管の再狭窄, 気管壁の軟化 による扁平状の狭窄, 治療部への肉芽増生や痽 痕化狭窄に対する気道内腔を保持する手技とし

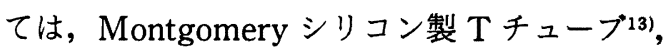
Souttarチューブ14), Dumonチューブ15)，われ われの改良したテフロン製直チューブ16)などの 挿入がある。

気管内に固定するチューブは，経験的に換気 障害を訴えない内径 $6 \mathrm{~mm}$ 以上のチューブの 挿入が必要である。また症例によっては $10 \mathrm{~cm}$ 以上の範囲に気管分岐部直上までチューブを挿 入し，移動しないように固定しなければならな w。

われわれは 1 年以上の生存が期待される例 や, 気道内径が $10 \mathrm{~mm}$ 以上に開大している腫瘍 性病変を除き, 気道維持のために安価なテフロ ン製の直チューブを捜入している ${ }^{16)}$ 。図 6 はわ れわれの行っているテフロン製直チューブの插 入, 固定法である。気管前面より硬膜外麻酔用 トフィー針を 2 カ所に刺入し, 持続麻酔用のカ テーテルを針よりロ腔に向かって挿入し, 症例 に合わせて作製したテフロン製直チューブに固 定用の太いナイロン糸を付けてカテーテルと系 をアロンアルファで接着させる。

次いで, カテーテル, 系の順に頸部より手繰 り寄せることにより, 気管チューブは気道内に 引き込まれ, 気管壁にナイロン糸にて結禁固定 される。1 回の内固定手術で最長11力月, 平均 5 カ月のチューブ固定が可能である。気管壁の 危弱化や糸の破損によりチューブが脱落するた め, 11力月間に同一例に 3 回の本手技の経験が ある。Montgomery のシリコン製 Tチューブ は高価でチューブが肉厚であり, Souttarチュ 
1) YAG Laser treatment

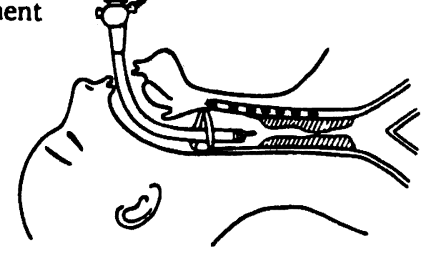

2) Measurement of the tracheal lesion Preparation of teflon tube

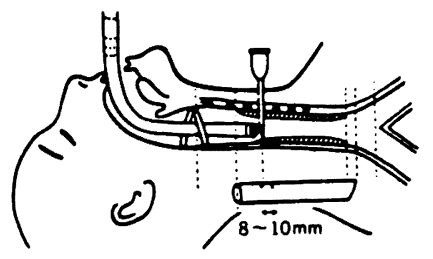

3) Puncture by Tuohy needles

Epidural catheter insertion



4) Catheter bonded to nylon thread

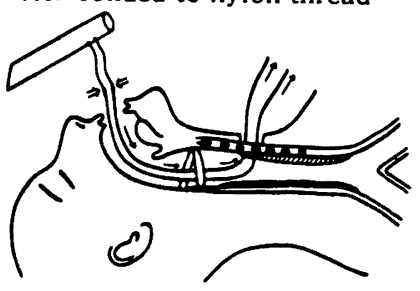

5) Teflon tracheal tube insertion

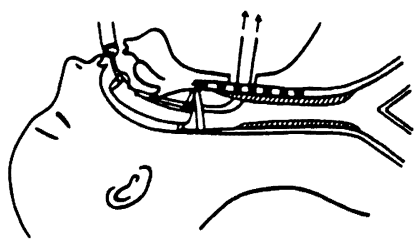

6) Fixation of tracheal tube

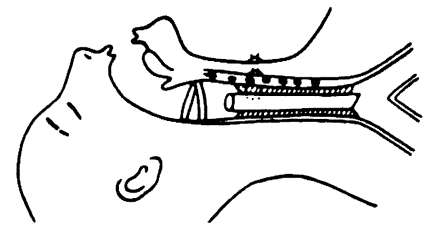

図 6 テフロン製直気管チューブの内固定留置術の手技

ーブは金属製の約 $3.5 \mathrm{~cm}$ 長のコイル状の材質 を硬性鏡下に插入する。

Dumonのシリコン製チューブも肉厚で挿入 時, 全身麻酔下に硬性鏡が必要である。シリコ ン製のチューブは壁厚が 1 ～1.5 mm あるた め, 最低の Performance Status を維持するた めに必要な内径 $6 \mathrm{~mm}$ のチューブ挿入を予定 すると, 外径 $8 \sim 9 \mathrm{~mm}$ のチューブを用意しな ければならない。ただし, 内径 $6 \mathrm{~mm}$ のシリコ ン製チューブは末梢側の喀痰の吸引などに使用 する気管支ファイバースコープの滑りが悪く， 非常に扱いづらい。

腫瘍性病変に対する気管チューブ内固定留置 術の適応となる例の多くは, レーザー治療後も 内径が $8 \mathrm{~mm}$ 前後であり, 気道内腔の凹凹が激 しく, シリコン製チューブでは挿入不能なこと が多い。テフロン製チューブは壁の厚さ 0.5 $\mathrm{mm}$, 壁が硬く, 気道内の突出病変を削ぎ切るよ
うにして気管内へ挿入できるため, 出血を伴う こともあるが，気道内径が $8 \mathrm{~mm}$ 以下であって も，換気状態改善に有用な実用的なチューブの 捰入が可能となる。

われわれが腫瘍性病変に気管チューブを内固 定した例は10例（表 1） ある。腺様豊胞癌は 2 例に直チューブ( 1 例は気管形成術後)，1例に

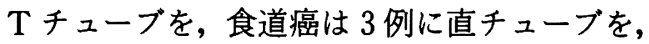

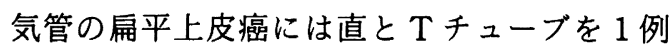

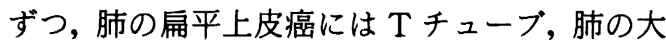
細胞癌には直チューブを, 甲状腺癌には $\mathrm{T} チ ュ$ ーブをおのおの 1 例ずつ挿入固定した。

腺様襄胞癌と食道癌の各 1 例はテフロン直チ ューブ摴入の11カ月と 9 カ月後, ブジー様効果 による内腔の拡大と気管内壁の滑沢な変化によ り，太いシリコン製 Tチューブを再固定しなお している。気管の腫瘍性狭窄に対するチューブ の内固定留置術を行うことにより，全例に呼吸 
状態の改善が見られ，肺機能的には高位肺気量 で患者の呼気努力の軽減に有効であった ${ }^{17) 。 た ~}$ だし，気管膜様部に巨大な腫瘤が存在する食道 癌の 1 例ではチューブが腫瘤を背側に圧排し， 逆に食道を閉塞して嚥下障害を併発した。腫場 性病変に対する気管チューブ内固定留置術が必 要な症例は 1 年以内に死亡する例が多い。ただ し, 換気状態を改善して積極的な化学療法と放 射線療法が可能であった肺大細胞癌や気管の扁 平上皮癌例では換気障害もなく $1 \sim 5$ 年にわた り生存した例がある。

\section{V．気管腫㿋に対する放射線治療}

レーザー照射後の局所に対する後療法として は, 外科治療を除くと, 放射線療法が最も期待 できる。原発性気管癌の中で最も発生頻度の高 い腺様㹕胞癌は，1970年代には放射線の感受性 が低い腫嚎と思われていたが，近年では感受性 の高い腫㰾であることが認識されてきた100。 れわれの症例ではレーザー治療後の原発性, 転 移性悪性腫崵の $56.9 \%$, 救急救命例に限っては $85.2 \%$ が放射線治療を受けていた（表 1，2）。

現在, われわれは気管病巣に外照射で full doseの照射がなされた後に再発した症例, あるい は再発の疑いや危険性のある症例に対しては ${ }^{60} \mathrm{Co}$ を用いての小線源による気管腔内照射 (Intraluminal irradiation)を行っている（図

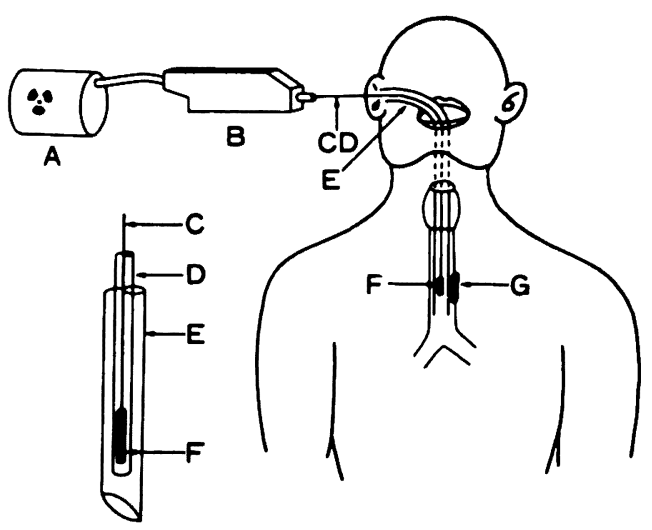

図 7 経気道的な小線源腔内照射法

$\mathrm{A}$ ：線源密封タンク B：アプリケーター固定器 $\mathrm{C}:$ レリーズワイヤー D : アプリケーター E : 気管插管チューブ $\mathrm{F} ：{ }^{60} \mathrm{Co}$ 線源 $\mathrm{G}$ ：腫場。
$7)^{6,18)}$ 。本法は気管支鏡検查に準じ, 局所麻醉下 に ${ }^{60} \mathrm{Co}$ 密封小線源を径気管插管チューブ内に 插入して $3 \sim 7$ 日に 1 回, 1 回 $5 \sim 10 \mathrm{~Gy}$ を 3 〜 回照射する。なお，われわれは外照射と腔 内照射により腫瘍が完全に消失した腺梯豪胞癌 を経験している。

\section{VI. 考 察}

気管，気管分岐部に増生する腫場は，気道狭 賃による強い呼吸困難を来し，予後を短期間に 悪化させる治療困難な症例が多い。呼吸困難を 主訴とする気管腫崵例にはまず第一に気管支鏡 的Nd- YAG レーザー治療により症状の寛解を 計るべきである(図 1)。このような症例に対す る救急救命的 Nd- YAG レーザー治療は，1980 年までは呼吸器の救急治療の中に記載されてな かった手技である19)。

レーザー治療後の全身状態, 腫瘍の増殖形態, 組織生検の結果から, 次の治療計画が立てられ る。原発性の良性腫瘍は，レーザー治療による 根治可能例が発見されるようになり, 気管形成 術の対象となる例が減少している。原発性悪性 腫瑒は増殖範囲が $6 \mathrm{~cm}$ 以下の気管環状切除, 形 成術可能例に対して，積極的に手術が行われる ようになってきている。

術後, 胸腔内手術では縫合不全による肉芽の 增殖と気道狭窄, 頸部手術では反回神経麻㾝が 致死的合併症の要因となるので, 予防的手術手 技, 術後管理を考慮しなければならない。

気管形成術の適応とならない症例に対して は, 放射線照射やチューブの内固定が行われて いる。Neville らの人工気管を用いての再建法 は 5 年生存例が報告されているにもかかわら ず20)，本邦ではわずかの施設で試みられている に過ぎず,チューブ内固定後種々の合併療法を 行った例との間に予後の差を認めないようであ る。

われわれが気管内固定チューブ留置術を行っ た例は, 原発性腫崵を除くと進行した病期师期, IV期の肺癌や食道癌であり, 基本的に気管の外 科切除が不可能な例である。これらの症例に対 する治療は, Performance Status を向上させた うえで放射線療法, 化学療法を可能な限り行う のが最も良い方法である。症例によっては気管 
支鏡的に注射針を用い, 気管病巣に抗癌剂や無 水アルコールを局所注入して腫瘍の壊死化を計 ることもある。放射線外照射が不可能な例には 腔内照射による追加照射が可能である。

1985年頃より，気管の腫瘍性病変に対する治 療法も, 他臟器癌と同様に, 集約的治療の考え 方が提唱されてきた。レーザー治療, 気管形成 術とチューブ固定術, 放射線外照射と腔内照射, 全身投与と局注による化学療法を症例に合わせ て合併療法として応用することにより, 気管内 の悪性腫瘍に対する治療効果がより高まり, 長 期間にわたりコントロールが得られるものと考 えている。

\section{VII. おわりに}

気管の腫瘍性病変のうち, 原発性腫瘍は早期 診断が困難である。多くの例は, 気管狭窄によ る喘息樣症状に対する治療を長期間なされてい る。喘息樣症状を訴える患者には常に気管腫瘍 を疑って気管支鏡的検査を予定するべきであ る。それにより，レーザー治療や気管形成術で 根治できうる腫瘍の早期発見が可能になると考 える。

\section{文献}

1) 新妻雅行, 中村治彦, 於保健吉: 気管腫瘍. 外 科診療, $28: 1341-1348,1986$.

2 ) 井上宏司, 石原恒夫 : 原発性気管腫锡の臨床. 日本胸部臨床, $44: 433-440,1985$.

3) 中村治彦, 雨宮隆太, 新妻雅行 - 他: 気管 - 気 管支原発腺样蘘胞癌の臨床的検討. 肺癌, 30 ： 313-318, 1990 .

4 ）石原恒夫, 加藤良一, 小林紘一・他：悪性腫瘍 に対する気管気管支形成術. 胸部外科, $42: 708-$ $711,1989$.

$5)$ Moon, B.C., Woolfson, I.K., Mercer, C.D., et al. : Neodymium : yttrium-aluminium gernet laser vaporization for palliation of obstructing esophagial carcinoma. J. Thorac. Cardiovasc. Surg., $98: 11-15.1989$.

6) 沖津 宏, 於保健吉, 内藤 淳・他：気管・気 管支への腫場浸潤・転移巣に対する内視鏡的 Nd-YAGレーザー治療及び合併療法に関する 臨床的研究. 日本胸部外科学会誌, 37 : 1187$1193,1989$.

7 ) 於保健吉, 雨宮隆太 : 気管支ファイバースコー
プを使用する内視鏡的治療法；Nd-YAGレー ザーを用いる方法.気管支ファイバースコピー, その手技と所見の解析 (第 5 版), pp. 208-240, 医学書院, 東京, 1989.

8 ) Oho, K., and Amemiya, R. : Endoscopic Nd: YAG laser treatment in airway lesion. "Advances in Nd:YAG Laser Surgery," Joffe, S.N., and Oguro, Y., eds., pp. 104-109, Springer-Verlag, New York, 1988.

9 ) Amemiya, R., Taira, O., Takizawa, N., et al. : Emergency endoscopic Nd: YAG laser treatment for tracheal and carinal lesion with ventilatory disturbance. "Nd: YAG laser in Medicine and Surgery - Fundamental and Clinical Aspects, Oguro, K., Atsumi, K., and Joffe, S.N., eds., pp. 301-305, Professional Postgraduate Services, Tokyo, 1987.

10) Pearson, F.G. : Advanced in tracheal surgery. "Advanced in Surgery, Vol. 16," Maclean, L. D., ed., pp. 197-223, Year Book Medical Pub., 1983.

11）雨宮隆太, 松島 康, 田近栄四郎・他：気管の 外科治療例の検討. 日本呼吸器外科学会誌, 3 : 51-62, 1989.

12) Ishihara, T., Kobayashi, K., Kikuchi, K., et al. : Does pleural bronchial wrapping improve wound healing in right sleeve lobectomy? J. Thorac. Cardiovasc. Surg., 89：665-672, 1985.

13) Montgomery, W.W.: Silicone tracheal Ttube. Ann. Otol., $83: 71-75,1974$.

14) Clarke, D.B.: Palliative intubation of the trachea and main bronchi. J. Thorac. Cardiovasc. Surg., 80:736-741, 1980.

15) Dumon, J.F.: A dedicated tracheobronchial stent. Chest, $97: 328-332,1990$.

16）雨宮隆太, 早田義博, 福田 豊: 気管内固定于 ューブ留置法. 外科治療, $27: 1503-1506,1985$.

17）松島 康, 雨宮隆太, 國井 司・他: 気管内固 定チュープに対する臨床的考察. 気管支学, 7： 55-61, 1985.

18) Nori, D., Hilaris, B.S., and Martini, N. : Intraluminal irradiation in bronchogenic carcinoma. Surg. Clin. North Am., $67: 1093-$ $1102,1987$.

19) Shiebel, E.M., and Moser, K.M. : Respiratory emergencies, The C.V. Mosby Co., Saint Louis, 1977.

20) Neville, W.E., Bolanowski, P.J.P., and Soltanzadeh, H.: Prosthetic reconstruction of the trachea and carina. J. Thorac. Cardiovasc. Surg., $72: 525-538,1976$. 